Line M. Bonde

\title{
Searching for the Self in Danish Twelfth-Century Churches: A Praxeological Experiment
}

\begin{abstract}
This article elicits statements about the medieval self from the Danish rural churches. It explores one ubiquitous style-making motif in Romanesque church architecture, namely the round arch. This "commonplace motif" is fused with practice theory to show how meaning-making arise in interplay between ritual practices, practitioners, and the churches' visual articulation. The article suggests that it is possible to explore aspects of perception by the participating self, but not the self as a traditional subject-based entity through this combined approach. The underlying objective of the article is to explore the twelfth-century churches from a non-conventional approach.
\end{abstract}

Keywords: Sunday mass, praxeology, ritual, liturgy, visual rhetoric

This article is, in essence, a methodological and theoretical experiment. It explores the limits of what can reasonably be said about the medieval self ${ }^{1}$ based on the rural churches of twelfth-century Denmark. Traditionally, these churches have been viewed as mute and thus redundant in relation to questions of medieval selfhood, cognition, and perception. The primary concern is, then, how we can get these buildings to talk, and to that, if and how they might testify to a notion of the medieval self. Conventional, discipline-specific approaches have proven to be insufficient in this regard. As such, the following article is an attempt at fusing different branches of current theories from the humanities and the social sciences in an effort to explore otherwise inaccessible information. More simply put: What did the visual articulation of twelfth-century churches intend? How were they used? And, might this intent and ritual usage inform us of aspects of the medieval self? In order to explore these questions, it will be useful to suggest a hypothesis to drive the discussion throughout the article. The working hypothesis to be tested on the material is thus: meaning-making

1 For a discussion of the concept of the self in the scholarly tradition, see the introduction to the present volume.

Line M. Bonde, MF Norwegian School of Theology, Religion and Society

Ә Open Access. (C) 2020 Line M. Bonde, published by De Gruyter. (c) BY-NC-ND This work is licensed under a Creative Commons Attribution-NonCommercial-NoDerivatives 4.0 International License.

https://doi.org/10.1515/9783110655582-014 
arises in the interplay between ritual practices, practitioners, and the churches' visual articulation.

In the article that follows, the twelfth-century Danish churches will first be presented from a non-conventional point of view. One ubiquitous visual articulation will be adressed, namely the round arch or the round-arched arcade. This motif is traditionally taken to be no more than a trite stylistic idiom. Contrary to the formalistic art-historical dismissal of this motif as devoid of meaning, the contention here is that this "commonplace motif" is in fact intended as visual rhetoric. The visual rhetoric is, in turn, activated and conditioned by the ritual practices unfolding both outside and inside the church building. As such, the commonplace motif is partaking in the meaning-making on the exact same terms as the individual practitioner or worshipper, if you will. In order to explain what is meant by all this, the twelfth-century rural church building, its physiognomy, and its usage will initially be characterized. By taking Sunday Mass as an illustrative example, the aim is to "activate" the physical remnants. The church's visual articulation will thus be juxtaposed with what we know of the ritual practices from the medieval Mass expositions (Messuskýringar 1962; Messuskýringar 2014). Having activated the church space(s), the article will then return to the abovementioned questions of the medieval self and embark upon the theoretical and methodological experiment proper.

As the churches are themselves - at first glimpse at least - mute with regards to their medieval users' meaning-making, just as the normativity of the expositions hardly reveals notions of medieval practitioners' perception, it will be useful to introduce a theory from the social sciences that discard the traditional dichotomy between "subject" and "object": namely, the so-called practice theory (see the introduction to the present volume). Generally speaking, this branch of social, cultural theory argues that meaning-making happens in practice only. As such, the material remnants are not merely things or objects to be interpreted by a subject. Instead, the same tacit knowledge is embedded in both subject and object. However, it is only expressed during the performance of the actual practice. The experiment is thus whether such an approach, when combined with commonplace theory, enables us to tease out information from the churches about the medieval self, which is not accessible with conventional discipline-specific methods.

\section{The Implications of Style}

The vast corpus of research on the Danish medieval churches was and still is rather conservative, in that it is primarily concerned with formal qualities. Two 
strands of classical approaches dominate the field, namely systematic, formalistic art history (that is, "history of style") and iconographical analysis. Consequently, the greater part of publications on the churches are either resonated catalogues and inventories minutely recording and categorizing the architectural features or its furnishings and fittings (quantitative descriptions of the original layout of the building, structural alterations and refurbishing throughout the centuries, spatial organization, typologies, workshops, etc.) or proper iconographic and iconological readings of pictorial programs or single monuments (e.g., wall paintings or sculptural carvings on baptismal fonts or portals). ${ }^{2}$ This pioneering bulk of research has contributed immensely to our knowledge of the first generation of stone churches built within the territory of medieval Denmark. It is now known that the vast majority of the more than 3,100 churches built during the long twelfth-century were small, rural churches and that they were generally uniform in their architectural layout and spatial arrangement (Kieffer-Olsen 2018; Wienberg 1993). A typical rural church comprised nave and chancel and was encircled by a cemetery. As shown in the schematic drawings Fig. 1a-c, this so-called two-cell building would have had two entrances: one to the south and one to the north. The church building would have had two or four small round-arched windows in the nave and between one and three windows in the chancel. Inside, the baptismal font was prominently situated on an elevated podium positioned almost at the center of the nave a bit to the west. Along the northern and southern walls ran low stone benches. The chancel arch, flanked by two side altars, provided access into the chancel, which housed the high altar. The building was fairly polychrome, exterior as well as interior. Wall paintings adorned the east wall of the nave and the chancel, while the sculptural details on portals, window openings, and chancel arches were coloured as well. Furnishings such as baptismal fonts and retables displayed decorative and iconographical details (for a more detailed account, see (Bonde [forthcoming])).

The formal analysis is thus vital to our immediate understanding of the physical church building, primarily as the stylistic criteria have been used to date the churches and identify impulses. The iconographical and iconological analyses, on the other hand, propose more or less historically verifiable meanings. ${ }^{3}$ However, when enquiring about intent or perception, as methodological tools, formalistic history of style and classical iconography can only go so far.

2 For a literary review, see Jürgensen (2018, 3-29). In recent years, a couple of studies that aim at covering the entirety of the building, its function, and their interrelations have come about. See especially the extremely thorough study of the churches' changing interior (Jürgensen 2018).

3 For the status of this strand of art-historical approach, see Liepe 2018. 
Besides, in the scholarly tradition guarding the Danish churches, questions like these have historically been dismissed as merely speculative or even as reductionist (see, e.g., Nyborg 1987). This is quite curious, as the uniformity in the architectural expression across medieval Denmark suggests, as a minimum, a relation between planning, constructing, and using.

In classical, art-historical scholarship, artworks (objects, artifacts, and architecture) are defined as human expressions particular to a historical period, which implies that any given work of art is a visual, tactile, or spatial expression specific to one mind or one culture. ${ }^{4}$ As such, the history of style - which has been almost synonymous with art history from its establishment as an academic discipline in the late-eighteenth century and well into the twentieth century ${ }^{5}$ - by definition entails a notion of "individuality"; be it individuality of an actual, specific individual, a people, a region, or a period (Wittkower 1973). Yet, the systematic strand of the history of style is extremely tendentious. It is conditioned by a nineteenth-century, formalist praxis of categorization that orders visual material according to a linear notion of progression or evolution of style based on modern connoisseurship. Despite its inherent focus on distinct traits and characteristics, questions of intent, meaning, and reception are rarely addressed as they are, essentially, irrelevant for the purposes of the stylistic exercise. Bluntly put, all visual articulations are in this line of thought tokens of the human "will to create" (Riegl 1893), rendering the exploration of meaning and intent somewhat superfluous. The will to create is understood as subconscious and universal (Gombrich 1979). However, the formalistic history of style has been heavily critiqued at least since the first quarter of the twentieth century and the very concept of style is continuously discussed (see, e.g., Lang 1987 or Pinotti 2012). A less formalistic and more anthropological understanding of the concept of style can be exemplified by the American art historian Meyer

\footnotetext{
4 This line of thought was cultivated by Giorgio Vasari (†1574) as early as the sixteenth century in his celebrated book Lives of the Artists (1550 and 1568) and became especially pronounced in the work of the discipline's founding father, Johan Joachim Winkelmann ( $† 1768)$, especially in his Gedanken über die Nachahmung der griechischen Werke in der Malerei und Bilhauerkunst of 1755. Moreover, this cultivation of an art historical canon (that is, a concern with high art determined by the Western academies) occasioned the rise the romanticist conception of the individual genius and the "master piece," a concept that survived well into the twentieth century.

5 Naturally, the discipline of art history has come a long way since it entered academia and a multitude of approaches and questions have been explored since then, slowly extending the boundaries of art history by crossing as well as appropriating theories and methods from neighboring disciplines (see, e.g., Preziosi 2009). In particular, the rise of poststructuralism in art theoretical discourse drew on general turns within the humanities more general: see, e.g., the works of the American art historian Michael Ann Holly, especially (Holly 1996).
} 
Schapiro's celebrated 1953 article "Style": "By style is meant the constant form and sometimes the constant elements, qualities, and expression - in the art of an individual or group." He elaborates:

The style is, above all, a system of forms with a quality and a meaningful expression through which the personality of the artist and the broad outlook of a group are visible. It is also a vehicle of expression within the group, communicating and fixing certain values of religious, social, and moral life through the emotional suggestiveness of form . . . The style reflects or projects the "inner form" of collective thinking and feeling.

(Schapiro 1953, 287)

Schapiro's definition of style as “constant form” implies integration of form and meaning. It is understood as a static entity and thus as something to be perceived of or interpreted by a subject. In this way, style becomes an object in its own right. Contrary to the classical iconographic approach of locating the specific written (Christian) sources as model behind an image, Schapiro contemplates style as an expression of social and ideological restraints, secular as well as sacred. The style of an object, then, be it a building, a painting, or a sculptural detail reflects an autonomous choice. However, as noted above, in the scholarship on Danish medieval churches, the systematic paradigm still reigns almost supreme. Therefore, this article returns to the visual articulation of the generic, rural church and propose quite a different way to approach its style.

All openings in the early stone churches were round-arched. At least they appear rounded. Many door openings were technically speaking constructed as rectangular openings with a lintel and only crowned by a semi-circular tympanum, which would have the entirety of the opening appear rounded. Therefore, it is crucial to notice that the semi-circular structure of the arch is not only used as a structural component reflective of contemporary know-how. Rather, rounded arches and arcades are frequently deployed as ornamental elaborations of the church building, on the furnishings, and as painted decorations. In fact, the round-arched "structure" or element seems to have been ubiquitous and a constantly repeated feature of this period (see Fig. 2a-e). Its ubiquity has caused the rounded arch to be regarded as the stylistic denominator of the so-called Romanesque style. The term Romanesque emerged with the establishment of the humanities in the eighteenth century. It was understood as a token of Roman lineage and as such implied that "something” Roman was intentionally imitated. Initially, Romanesque was used exclusively to describe coarse masonry buildings in Western Europe erected after the Fall of Rome and before the Gothic era. However, it soon came to characterize a variety of architectural expressions from all over Europe and within a loosely defined and rather lengthy period (spanning from the sixth or eighth century to the twelfth or thirteenth century). The problems involved in defining the Romanesque 
style can be exemplified in the words of the English art historian Eric Fernie: "It is supported by the clarity of its main characteristic, which is most often seen, in all the visual arts but especially in architecture, as the articulation of parts from smallest to largest, forming clear geometrical shapes which relate to one another in understandable ways" (Fernie 2010, 295). In the Danish context, the term Romanesque is usually used to date sacred architecture and artifacts from the period between c. 1100 and $1250 .{ }^{6}$ Nevertheless, Romanesque architecture, in the broadest sense, is traditionally understood as having the same point of reference, the Roman Empire, literally meaning "in the Roman manner.” Moreover, it is an established convention to distinguish between the rounded Romanesque arch and the succeeding Gothic pointed arch: the example par excellence of the idea of the evolution of style.

Systematic art history has more or less written off the rounded arch as a whim of fashion and thus as devoid of meaning. Contrary to this, this article claims that this common and repeated motif - monumental as well as decorative - was intended to function as a memory-based framework of related stories activated by ritual practices. As argued elsewhere, it is

exactly because the semi-circular arch is commonplace in the rural churches, [that] I propose using this exact term and labelling the semi-circular motif a "commonplace motif." Commonplace, however, is not to be understood as a platitude. By contrast, I suggest using this notion as it derives from the Classical Latin locus communis, designating "general arguments, which do not grow out of the particular facts of a case, but are applicable to any class of cases.” The point is thus that this motif by its very nature is in flux, and as such, it constitutes a dynamic interplay between the conventional static categories of ornament, iconography, microarchitecture, and monumental architecture. From this follows, I claim, that the same exact motif must be flexible in its rhetorical implications, essentially encompassing a scale from "explicit representation" to "trite stylistic denominator" depending on recipient and setting. Yet, even the "empty characteristic" of a style still embeds its parental origin; be it actively acknowledged or just chosen on purely aesthetic grounds.

(Bonde [forthcoming])

Approaching the churches' style - or visual articulation, if you will - from a rhetorical standpoint allows us at once to rise above the material remnants while still effectively grounding the interpretations in them. In this way, the commonplace motif as defined by commonplace theory escapes the methodological pitfalls of, for instance, fixed intentions. As such, it is in opposition to Schapiro's claim that style is "constant form." Rather, style as a "vehicle of expression" is arguably in constant flux. Meaning is not solely defined by the autonomous

6 An extensive discussion of the term Romanesque and its usage can be found in my forthcoming dissertation. I have also touched upon the subject in (Bonde [forthcoming]). 
stylistic choices of an artist or patron. While meaning is by definition embedded in form - as a mixture of continuity and change - it is continuously negotiated in the meeting with recipients. Meaning arises not only by way of form. It arises in interplay between various factors. Therefore, in our search for the medieval self, we have to transcend the traditional discipline-specific boundaries: because, if we accept that meaning is never fixed, it follows that neither is style nor selves.

The rhetorical implications of commonplace theory accommodate the multilayered plurality of meanings inherent in medieval cognition and thus in medieval material culture (Carruthers 1990, 1998, 2013). By using this approach, we might be able to explore a notion of the self from the Danish churches. We can discuss, for instance, the seemingly basic question: What can the physical remnants tell us of medieval meaning-making? By accepting that the commonplace motif has a rhetorical function, it follows that some sort of meaning-making occurs when the church is in use, is activated. The question then arises as to where we might locate this meaning-making: in the self, in the material commonplace motif, in the ritual practices, or perhaps in their interplay?

\section{Activating Space: The Ritual Movements of Sunday Mass}

In order to explore the role of the material commonplace motif in the process of meaning-making, we have to gain an understanding of just how the churches were used. ${ }^{7}$ We have to get a tentative idea as to how the ritual practices, for which the churches were built, utilized the actual, physical building and its visual articulation. The aim is, in other words, to explore to what extent it is possible to "activate" a (re-)constructed space from a remote past. It should be stressed, however, that this is not just gesturing at the geometrical space defined by the physical walls. No, this also concerns the populated space, the social space, the dynamic space. As such, two things are presupposed: 1) that space(s) and the perception or experience of the space(s) are cultural phenomena, which in turn are always socially constructed (following the definition by Lefebvre 2009), and 2) that space(s), ritual practices in space(s), and the practitioners in said ritual practices are in continuous interplay and thus prerequisites for meaning-making.

7 Parts of this subsection is also included in (Bonde [forthcoming]). 
To illustrate and further explain what is meant by this, and as there are no Danish written expositions from the period in question, the following "activation" will be based on the medieval Mass expositions written in Old Norse (namely, the compilation Messuskýringar comprising texts dated between 1150 and 1500), as these, with all reservations, in the main follow Continental European practices. ${ }^{8}$ It is arguably justifiable to use the Norse expositions, as it is very unlikely that the ritual practices in the Danish churches would diverge noticeably from the Nordic practices. Nevertheless, one could easily mention a variety of notorious methodological problems involved in dealing with the relation between church architecture, symbolism, and function (function here understood as the ritual practices performed in a consecrated space) (see, e.g., Crossley 1988). However, it should suffice here to only briefly reiterate that the normative Mass expositions, of course, cannot be taken as evidence of how the rituals were actually performed - especially not when it comes to the rural churches. This being said, the expositions do provide us with a glimpse of the medieval ritual practice as it would ideally have unfolded around and inside the church. Moreover, and as discussed above and hopefully illustrated in Figs. 1a-c and 2a-e, the uniformity in spatial layout, furnishing, and overall visual expression in the Danish twelfthcentury churches allow us to assume as a bare minimum that a) Mass was celebrated, as we can see from the altars, b) that baptisms were performed, as established by the font's prominent position in the nave, and c) that funeral rites were held, as indicated by contemporary burials in the surrounding area of the church. All of these different rituals involved, of course, ritual practices. In the following, the focus will be on the liturgy of Mass, as this was one of the most frequently performed rituals in the rural churches. It should be noted, however, that the movements described here and shown in Figs. 3a-c are expressions of an ideal solution and are based on my interpretation of the Old Norse text compilation.

A basic liturgy of Mass, meaning one stripped of all "extra" ceremonial splendor, required as a minimum a priest and preferably also a clerk or an altar boy. In principle, no congregation was needed, but for the purposes of this article, we will

8 Messuskýringar 1962. The Norse collection was first published by the Norwegian church historian Oluf Kolsrud in 1952, albeit in a non-normalized edition. Kolsrud's edition contains the following Norwegian and Icelandic manuscripts: AM 237 a fol, AM 238 XXIII fol, AM 238 XXVI fol, AM 619 4to (also known as The Norwegian Homily Book, published in Gamal norsk homilebok 1966), AM 624 4to, AM 625 4to, AM 672 4to, AM 435 12mo, Holm perg 5 fol. Holm perg 15 4to (also known as The Icelandic Homily Book, published in Icelandic Homily Book 1993), RA Skokloster E 8822 fol. For a synthetic, annotated edition with a modern translation (modern Norwegian), see Messuskýringar 2014. For the European practices, see, e.g., Durand 1995. 
include a congregation and thus focus on Sunday Mass. Sunday Mass was the ceremonial core of the medieval, rural parish and most probably the time of the week when the Church met the worshippers. The ritual started outside the church, ${ }^{9}$ presumably in front of the main entrance, which in the case of the Danish rural churches would be the southern portal. The worshippers were blessed with holy water before walking in procession around the church, moving east to west (Fig. 3a). Returning to the main entrance, a prayer was said and the procession entered the church (Messuskýringar 1962, 38-9; Messuskýringar 2014, 93). Inside, the priest and clerk walked down the nave and stepped into the chancel area. The priest would then kiss the altar and kneel before it, accordingly initiating Mass (Fig. 3b). From this moment, the priest would not leave the chancel area before Mass was over (Fig. 3c). Thus, a multitude of minor ritual movements was restricted to this area. The priest and the clerk would then perform Mass in what seems to have been an interplay between the two. Whoever performed whichever part of the ritual, the only instance, it would seem, of leaving the chancel area during the celebration was when Gradual was sung and perhaps at "the sign of peace." According to the Old Norse expositions, Gradual was "often sung below the staircase" (at á pollom er funget ıðola), ${ }^{10}$ which can only be understood as on the floor level of the nave in front of the chancel arch, as only one or a few steps would lead up to the chancel (see Fig. 1c). Moving on to the climactic part of Mass, it is stated that a book should be presented to perform "the sign of peace" and that "the kiss of peace moves among all present” (oc fiðan fer friðar koff allra manna á miðlı tıl peirrar). ${ }^{11}$ How and to what extent this happened is of course impossible to say. ${ }^{12}$ The culmination of Mass, the Eucharist, was also performed inside the chancel area and the Communion itself was most likely just taken by the priest, which essentially completed the celebration. Of the exit from the church, there is a paucity of information. It is merely noted that holy water was sprinkled on the congregation before they left the church. If this were indeed customary, it would probably have meant that the priest or the clerk would descend from the chancel in

9 This is only described in AM 625 [dat. 1470], yet in the famous compilation by William Durand of Mende the vidi aquam / asperges me seems to have been a convention from quite early on (Durand 1995, 240ff.), Liber qvartvs.

10 My paraphrase of text A (AM 619 4to (1200-1225) in Messuskýringar 1962, 16). See also Messuskýringar 2014, 74.

11 My paraphrase of text A (AM 619 4to (1200-1225) in Messuskýringar 1962, 23). See also Messuskýringar 2014, 75.

12 In Continental sources, it is usually a so-called pax that should be presented and kissed. The pax could take many different shapes or forms. There are, for instance, examples of ivory carvings mounted on handles. Yet, a book cover with a plaque could also constitute a pax. 
order to carry out this last part (Messuskýringar 1962, 24-5, 39; Messuskýringar 2014, 76, 94).

Now, having tentatively activated the church building and one of its usages, we might notice that both types of sources (that is, the material remnants and the written expositions) are, indeed, remarkably silent when it comes to conceptions of individuals or selves. So, how are we to locate a notion of the self from the rural churches? Posing this question conveniently brings us back to the working hypothesis stated in the introduction: namely that meaning-making arises in interplay between ritual practices, practitioners, and the churches' visual articulation. In this definition, the self is part of the overall meaning-making (as practitioner) on the exact same terms as the churches' visual articulation and the usage. As is hopefully clear by now, the working hypothesis takes as its underlying assumption commonplace theory's rhetorical implication, namely that meaning making is in flux. Moreover, and as we shall see below, commonplace theory, therefore, draws on or rather cooperates with the praxis-oriented brand of social, cultural theory, namely practice theory.

\section{Fusing Theories: The Decentralization of the Subject and the Affectivity of Practice}

As just described, the ritual practices in the rural churches involved movement in space(s), and movement in space(s) implies bodies and materiality. Whereas the fixities of especially the interior arrangement of furnishings clearly suggest that bodies were supposed to move about them, the remnants are still silent as to what their visual articulation intended. How were they perceived during practice? Neither the buildings nor the written expositions inform us the degree of participation by the congregation, let alone of perception or self-apprehension during the practice! We should, however, keep in mind that active participation in the ritual practices by the individual member of a parish (which was crucial in late-medieval devotional practices) was essentially not required. The parish priest "was the agent designated to perform the communication with the divine on behalf of the gathering" (Jürgensen 2018, 444).$^{13}$ Likewise, the Old Norse texts only offer occasional comment on participation. Formulations regarding participation are thus in first-person plural: "We sing this song as we greet the priest,

13 This is also the reason why the degree of lay church attendance in rural, twelfth-century Denmark is still heavily debated. 
who brings forward sacrifice to God in peace for us." (Af | pyı fỷngom yér pan fong at yer tokom kenne mann er fóın yıll føra .Guðe. tıl frıðar oss.). ${ }^{14}$ Other formulations merely imply an audience, or, the wording is as if stated by a beholder, although not necessarily a participant. For instance, it is stated that everyone should bow their head at a specific song, that the kiss of peace should move among all present, that holy water should be sprinkled on everyone present, and that some of the holy water should be brought back home by the congregation so as to bless their home (Messuskýringar 1962, 38, 44; Messuskýringar 2014, 93, 99). The lack of active participation by the congregation, naturally, complicates our exploration of meaning-making and search for the self in the Danish churches.

The formalistic, style-historical understanding of the round arch as a trite, stylistic denominator cannot be used as a methodological tool when asking about the self. The underlying basic assumption in a conventional art-historical line of thinking is that the arch or arcade only is in some or other "relation" to a human subject: that is, as a purely aesthetic product of or as conceived by said human subject (i.e., an asymmetric relationship between subject and object). Moreover, we have no written sources from contemporary, worshipping participants that might testify to their perception of the church's visual articulation or understanding of the ritual practice. At this point, then, it seems only reasonable to revoke the rhetorical implications of commonplace theory and claim that the commonplace motif as a non-human, yet human-made, object embeds the same tacit knowledge as the human subject. The question then arises as to how we might access this shared tacit knowledge and whether or not it reveals information of a medieval self. This is where theories of "the social" might prove useful. More specifically, this article turns to practice theory as formulated by the German sociologist Andreas Reckwitz in his two interrelated articles of 2002 (2002a and 2002b). ${ }^{15}$ Reckwitz essentially combines the French philosopher and ethnographer Bruno Latour's Actor-Network Theory (ANT) (Latour 1993 [1991], 2005) with an idealized version of the early praxeological thinking of the American philosopher Theodore Schatzki (1996). Moreover, combining the rhetorical and practice-based approaches offers a heuristic potential for including

14 My paraphrase of text A (AM 619 4to (1200-1225) in Messuskýringar 1962, 11-12.) See also Messuskýringar 2014, 71.

15 As the identity of praxeology is still debated (Postill 2010; Schatzki, Knorr, Cetina, and von Savigny 2001; Hui, Schatzki, and Shove 2017), it should be noted that this article will be operating with only this one specific strand of second-generation practice theory. I have taken the liberty of summarizing this theoretical extrapolation as the "Reckwitzian" version of practice theory. 
considerations of the aesthetic dimension of "atmosphere" (emotions, feelings, and affects), which in turn permits a discussion of the self.

Practice theory - and ANT for that matter - distinguishes itself from the materialist / idealist ways of thinking, as well as from the culturalist / linguist traditions, by promoting a flat ontology of human and non-human actors (Latour 1993 [1991]). Therefore, Reckwitz (2002b, 246) puts much energy into carefully mapping out their main divergence; that is, the place of the social. ${ }^{16}$ In the cultural (linguist) theories, the social is always "connected with symbolic and cognitive structures of knowledge,” (Reckwitz 2002b, 247) however, in quite diverse ways. Nevertheless, it is always placed in the mind of the subject, just as was seen to be the case in the conventional art-historical approach. Objects and happenings are to be interpreted by subjects in order for meaningmaking to occur within the subject. In stark contrast, the praxeological thinking (obviously) places the social in practices; meaning, the social is understood as "a routinized type of behaviour which consists of several elements, interconnected to one another" (Reckwitz 2002b, 249). The subject is thus decentered, as the

conventionalized "mental" activities of understanding, knowing how and desiring are necessary elements and qualities of a practice in which the single individual participates, not qualities of the individual (. . .) A practice is thus a routinized way in which bodies are moved, objects are handled, subjects are treated, things are described and the world is understood.

(Reckwitz 2002b, 250)

The fundamental problem with the culturalist / linguist theories is then, according to Reckwitz, that "the material entities do not appear as things to be handled, but as objects to be interpreted" (Reckwitz 2002a, 208), effectively evoking Latour's object-oriented flat ontology. Along with Latour, Reckwitz argues that a practice consists at once of both human inter-subjectivity and non-human inter-objectivity. In other words, things or objects are constitutive for social practices in the exact same way as humans are (Reckwitz 2002a, 208-9; 2002b, 253): they have the same degree of agency. This Latourian concept is then fused with the praxeological thinking of primarily early, Wittgensteinian inspired, Schatzki (Schatzki 1996), which enables Reckwitz to redefine things as "irreplaceable components of certain social practices (. . .) in their being 'handled' in certain ways” (Reckwitz 2002a,

16 In his two complimentary articles (Reckwitz 2002b, 2002a), Reckwitz outlines the theoretical developments within the social sciences, or more specifically to and within the theories of culture. It might even be possible to argue that he understands these theoretical shifts or patricides as necessary stepping-stones toward the ultimate goal of practice theory as a coherent heuristic device. The point of this is also to make a clear distinction between Reckwitz's construct of a "purified" practice theory on the one hand, and the diverse praxeological remarks made by the broad movement of theorists within social, cultural theory on the other. 
210). In this way, the repeated "doings with things," this "regular bodily activity" is comprised by interplay of a presupposed specific, practical knowledge of how to handle the particular thing; a knowledge both determined by - while determining the thing. As such, in the Reckwitzian praxeological approach, things are "materialized understandings," which basically means that the same tacit knowledge can be found in both the human subject and in the non-human object (Reckwitz 2002a, 211-2). This definition, as we recall, is implicit in our working hypothesis.

It must be asked along with the "Reckwitzian" praxeological thinking to what extent it is possible to understand the visual articulation of the commonplace motif and the commonplace movements described in the expositions as (parts of) a social practice. And, in turn, if and how a social practice might provide information about a medieval self. This is essentially the experiment. To do so, this article will pay special attention to the Reckwitzian approach to artifacts and their agency and thus to the artifact's place or role in establishing social practices, essentially as artifacts are understood as co-generators of meaning.

\section{Affecting the Self through Commonplace Movements: An Experiment}

In the above walk-through of the liturgy of Mass, all minor movements by the priest and clerk inside the chancel area have been omitted, as they mainly follow the standard regulations of continental European practices and are of little concern to the overall argument in this article. Instead, the article highlighted the largescale movements to demonstrate that they are centered on the two primary thresholds of the church building, namely the portal and the chancel arch (see Figs. 3a-c). This observation is in itself not surprising, as numerous studies of the liminality of the threshold have been carried out since van Gennep published his seminal "Rites of passage" over a century ago. ${ }^{17}$ Nevertheless, the reason for emphasizing the ritual's focus on the thresholds is not the liminality per se. Rather, the reason lies in the working hypothesis that meaning-making arises in the interplay between the ritual practices, the practitioners, and the churches' visual articulation. In other words, the visual articulation of the commonplace motif is a vital part of the ritual practice and, thus, of the meaning-

17 Gennep 1981 [1909]. With regards to the Scandinavian churches and their rites, see especially Andås 2007. 
making in said ritual. However, as shall be seen below, it is not just the roundarched wall openings that partake in the meaning-making. All instances of the semi-circular commonplace motif - ubiquitous, inside as well as outside - are part of the meaning-making.

The social practice of viewing Mass or attending Mass in the twelfth-century churches would, in a praxeological line of thinking, constitute the routinized doings or handling of things. The "thing," in our case then, would be the physical church building. What is of special interest to the present purposes is that meaning-making lies in the routine practice, that is to say, in the repeated ritual in and around the church. The church spaces, in plural - be it the outside or the inside constitute, then, what Reckwitz has labelled "affective spaces" (Reckwitz 2012). These spaces are products of "matches between atmospheres and sensitivities" (Reckwitz 2012, 255), which are activated by the routine practices. By including (parts of) the aesthetic theory of German philosopher Gernot Böhme (1993), Reckwitz $(2017,117)$ objects to the widespread assumption in sociology that affects are "non-social, non-cultural phenomena occurring within individual's bodies or individual's psyche," that is, internal to the subject. ${ }^{18}$ Instead, he claims, affects are part of practices, in that affects are social and thus by definition not subjective. Affects are activities, and they are bodily arousal or excitement spurred by the social and space(s). Affects are "properties of the specific affective 'attunement' or mood of the respective practice," that is, exterior to the subject (Reckwitz 2017, 119). Moreover, affects are at once material and cultural and are thus general phenomena of every single practice (Reckwitz 2017, 118-9). The main point is, more simply put, that from "the view point of the human subject, it can be said that the affectivity of a practice comprises specific stimulations attached to other people, things or ideas" (Reckwitz 2017, 121).

So, what Reckwitz is essentially arguing is that spaces should not be regarded as mere producers of meaning in a recipient, because "affects only form when a space is practically appropriated by its users, which always activates these users' implicit cultural schemes and routines” (Reckwitz 2012, 255). The flat ontology argument posed here, obviously, implies that affectivity is always a result of the co-presence and interaction of the human subject with the nonhuman object - it is an external property to the individual. The externality implied here is also external to the churches and their visual articulation. From this

18 It should be noted that Böhme is not a praxeologist. Rather, he has propounded a phenomenological atmosphere theory (an ecological aesthetics), essentially rejecting the traditional Hegelian definition of aesthetics by claiming that atmosphere is existential. Thus, Böhme's aesthetics are based on a theory of perception in which the human bodily experience is only in coexistence with the specific environment (atmosphere). See, e.g., Böhme (1993). 
follows that the tacit knowledge, the seeds of potential meaning-making, which are embedded in the material remnants, by definition would have existed in the medieval subject experiencing the church through the ritual practice. The point here is, in other words, that by exploring the intent in the churches' visual articulation, we are simultaneously exploring the potential meaning-making in the ritual practice and thus aspects of perception by the participating self.

The art historian is usually left with only a general idea of how a twelfthcentury, rural church was in fact constituted, while the written sources tell of how the church was ideally used. Looking at the schematic drawings of a rural church building, it quickly becomes apparent that the thresholds on which it was just seen that the largescale movements were centered are essentially monumental examples of the round-arched commonplace motif (Figs. 2c, e). As such, they constitute a vital part of both the practice and of the "thing to be handled." As already stated, according to commonplace theory, the roundarched motif has the potential to function as a memory-based framework of related stories activated by ritual practices. These stories are in turn conditioned by a cluster of biblical metaphors, which defined the medieval world view. ${ }^{19}$

Fusing commonplace theory with the Reckwitzian take on practice theory, we could say that, potentially, three types of meaning-making or productions of meaning could occur during the celebration of Mass. First, the exterior practice of gathering in front of the portal and the following procession around the church building terminating again in front of the same portal before entering has the potential to - at the very least - spur an expectation of entering, which culminates in the actual entering of the church through the portal, a monumental commonplace motif (Figs. 2c, 3a-b). During Mass inside the church, the second type of meaning-making could be spurred. From the nave - through the chancel arch, yet another monumental commonplace motif - the worshipper witness glimpses of ritualized movements and the handling of sacred objects by the priest. As previously described, actual contact between the affective spaces of the nave and the chancel could be communicated through the pax or "kiss of peace," which would generate a movement in the worshipper towards this new focal point - yet only momentarily before it retreated back through the chancel arch again. This suggests the promise of entering the most holy, potentially alluding to both the physical chancel and to the Heavenly Jerusalem. The third possible meaning-making is exterior as well as interior. It once again pertains to

19 This is argued and elaborated in Bonde [forthcoming]. All of the related stories are in turn conditioned by the Christian story-world; for this concept, see Aavitsland, Oftestad, and Zorgati [forthcoming]. 
the commonplace motif, which we saw to be ubiquitous in the visual expression of the churches. However, it now pertains to the non-monumental motifs, those traditionally dismissed as mere stylistic decoration. For instance, during the procession around the church - even before entering - you would see the semi-circular structure of the arch in the window openings, in wall recesses, or, even on the base courses (Figs. 2a-b). The same could be repeated on the arches found on the inside of the church, for instance, the arcades running along the baptismal font or framing biblical narratives in the murals (Fig. 2d). The notion of entering is here only possible through allusion. The routinized bodily practice of attending Mass can thus be understood as a practice of "entering." More simply put, one could claim that the three types of meaning-making just described are determined by degrees of contact with the Divine; 1) the physical or complete contact - that is, actual entering through the portal; 2) the limited physical contact of observing through the chancel arch and perhaps even touching parts from the most holy area; and 3) the restricted and optical only contact of solely viewing through the peepholes of the arcades to the otherworldly. What is important here is that the commonplace motif is not merely a frame in the shape of the Romanesque arch. Rather, its insisting presence adds to the process of meaning-making. It has a clear intent and role to play. As such, all of the arches and arcades generate affectivity in co-existence with practice and practitioner.

The practice of entering - physically or by allusion - is thus strongly inherent in the practice of attending Mass in the twelfth century, as may be testified by the physical remnants. The production of meaning, then, if we accept this argument, is thus channelled through the commonplace motif of the arcade when activated by the practice and affectively experienced.

\section{Conclusion}

The self has been at the center of the classical theories in the humanities, as well as in the social sciences, since the very beginning. What is particular to the Reckwitzian practice theory is, among other things, that the self is decentered and that the "affective structure of a practice explodes the inside / outside binary, by being internal and external at the same time" (Reckwitz 2017, 119). The self is neither autonomous nor norm-following, and agency is implicit in human subject as well as in non-human object and in the social practice itself. This leaves no room for a self in a linguist or classical cognitive sense. However, it is not possible to explore the self as a traditional subject-based entity through the visual articulation of the churches. The sources simply do not allow it. So, if we 
want to explore a notion of the self through the material remnants of the rural churches, we have to think differently. Thus, and as stated in the introduction, this article has been a theoretical and methodological experiment. It is my firm conviction that revisiting the churches equipped with novel theories enables us to extrapolate otherwise inaccessible information. By fusing commonplace theory with the Reckwitzian praxeological thinking, it was possible to test a working hypothesis concerning meaning-making in the churches, which in turn allow us to say something about the self, albeit not about a specific self.

The affective space(s) in and around the churches are imbued with meaning. At least parts of the potential meaning-making are, arguably, accessible. The rhetorical quality of the commonplace motif in itself embeds a plurality of potential meaning-making - meaning-making that is conditioned by and released only when activated in a practice. The main point is thus that the visual articulation of the churches embeds a knowledge of past "handling." This handling mirrors a mental or cognitive tacit knowledge that would presumably have been embedded in a medieval worshipper, as a practice presupposes knowledge in order to be carried out. Does this, then, tell us anything about the self? It can be argued that it does not tell of a specific, autonomous self, in the modern sense of the word. Instead, a commonplace self or properties of a participating self can be deduced. As such, the concept of the self is understood as a "selfhood" included in a collective or group, partaking in a practice. The motivation is an integral part of the practice, and the affective atmosphere that arises in the meaning-making is indeed constituted in an interplay between space(s), commonplace motifs, and the practitioner.

However, the reader might wonder, at this point, what would be so different about the pointed arch as the commonplace motif? The immediate answer would be nothing. The pointed arch can indeed be understood as a commonplace motif, as this architectural motif is used in much the same way as the rounded arch. However, there are important differences to be noticed - especially when asking for meaning-making. Commonplace motifs, as phenomena, are neither tied to the round arch nor to a specific period of time. Instead, commonplace motifs are subjects to both continuity and change. The pointed arch may be understood as a modernization of the rounded commonplace motif. However, in the Danish churches, the pointed arch (or rather four-centered arch) ${ }^{20}$ co-exists with the rounded arch. As such, the two commonplace motifs informs one another. In this way, some 'original' meanings probably disappeared, while new ones arose.

20 Almost no genuine Gothic, rural churches were built in Denmark. Rather, the older Romanesque ones were subject to disparate renewals; see Jürgensen (2018). 
The point is, in other words, not to suggest that there is only one commonplace motif. There is a plethora of commonplace motifs. Some are deployed simultaneously / in parallel within the same buildings. This seems to have been the case in, for instance, the Danish churches in the centuries following their erection, and in fact all the way up to the present. Meaning-making, therefore, is in constant flux, just as style and selves are. ${ }^{21}$

As is hopefully also clear by now, an underlying objective in this article besides the immediate value of exploring the twelfth-century churches from a non-conventional approach - has been to discuss more generally the applicability of the social theories within the humanities, especially their usefulness in academic disciplines primarily concerned with historical and material remnants. As for the study of the Danish medieval churches, new perspectives have been wanting for a long time, and experimenting with theories across conventional disciplinary boundaries might prove useful. If nothing else, experimenting might provoke fruitful new discussions.
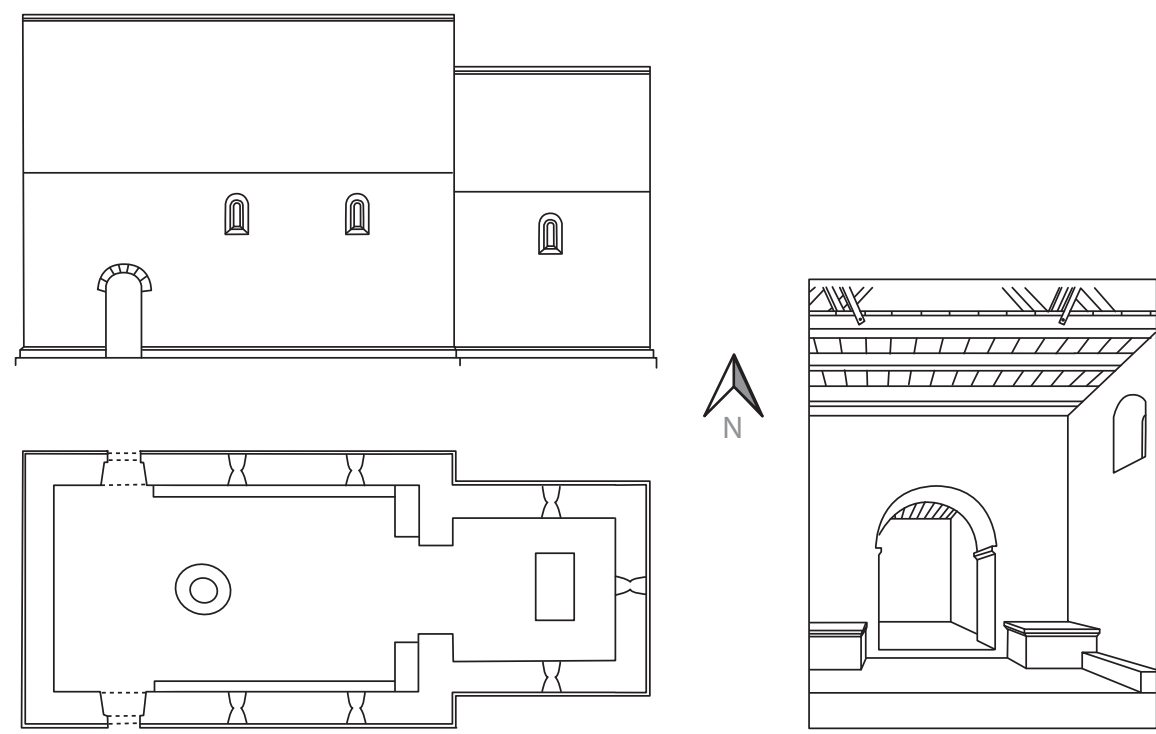

Figure 1: Elevation, plan, and cross-section of a generic, Danish rural church from the twelfth century. After Danmarks kirker, Fagordbog. Altered and supplemented by the author. Digitized by Kim Bonde 2019.

21 This aspect of the commonplace motif is subject to thorough discussion in my forthcoming dissertation. 

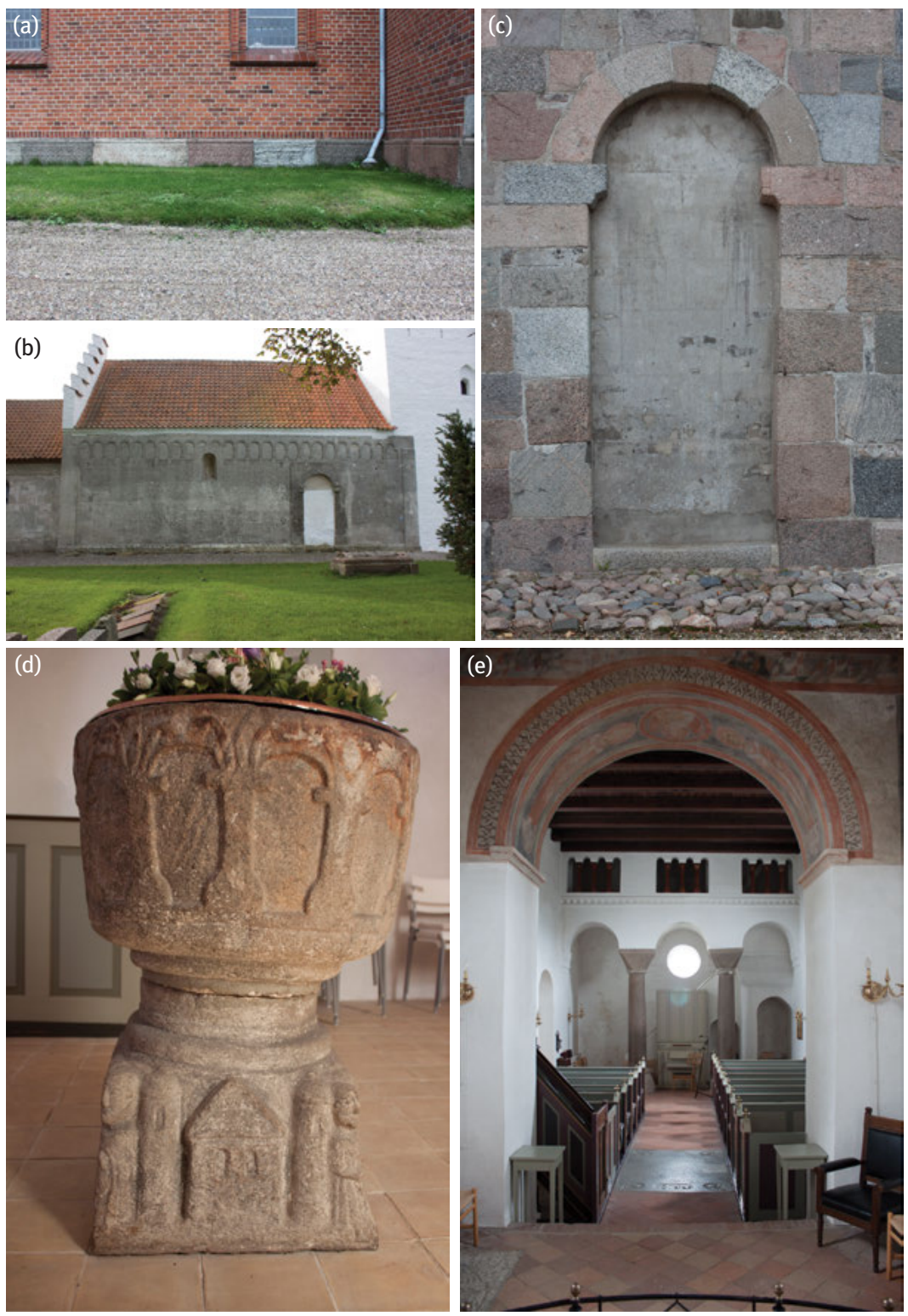

Figure 2: Random selection of details from twelfth-century churches, Denmark. (a) Arcade carvings, base courses, Bjerreby Church, Funen. (b) Blind arcades, exterior recesses, Hammelev Church, Southern Jutland. (c) Portal, Borup Church, Northern Jutland. (d) Arcaded baptismal font, Jegerup Church, Southern Jutland. (e) Chancel arch, facing West, Tveje Merløse Church, Zealand. Photos by the author 2017-2019. 
(a)

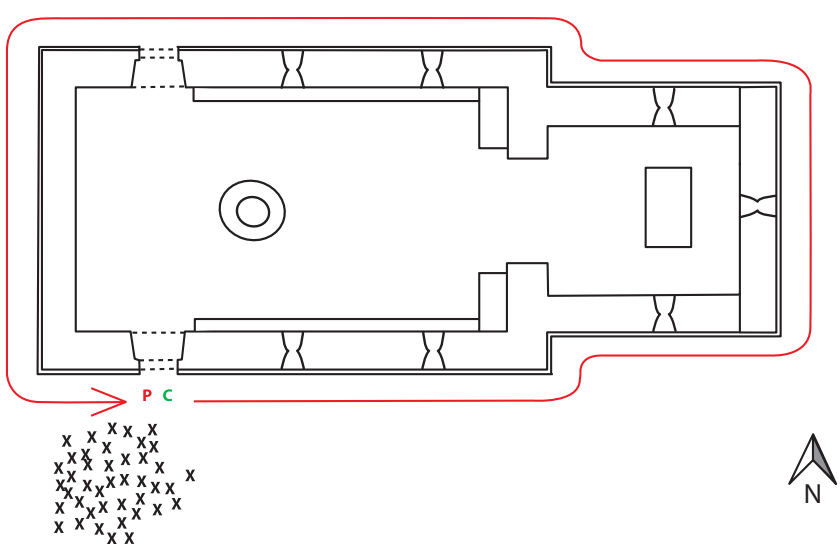

(b)

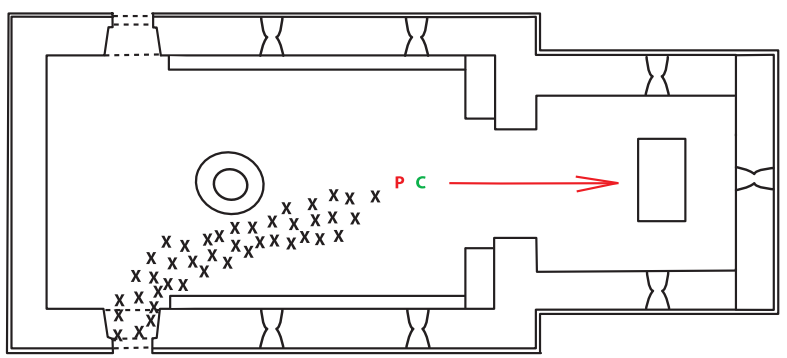

$\widehat{N}$

(c)

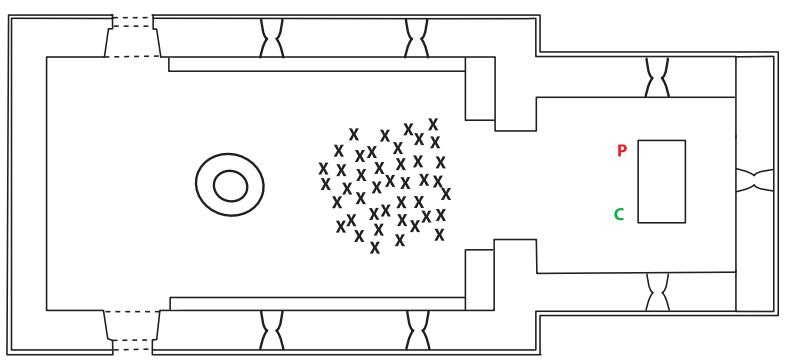

$\widehat{N}$

Figure 3: $(a-c)$ Interpretation of large-scale movements involved in Sunday Mass. $P$ is priest, $\mathrm{c}$ is clerk, $\mathrm{x}$ are worshippers.

Drawn by the author. Digitized by Kim Bonde 2019. 


\section{References}

\section{Primary Sources}

Durand, William. 1995. Gvillelmi Dvranti Rationale divinorum officiorum I-V. Ed. A. Davril and

Timothy M. Thibodeau. Corpus Christianorum. Continuatio Mediaeualis, 140. Turnhout. Gamal norsk homilebok: Cod. AM. $6194^{\circ}$. 1966. Ed. Gustav Indrebø. Oslo.

The Icelandic Homily Book, Perg. $154^{\circ}$ in the Royal Library, Stockholm. 1993. Ed. Andrea de Leeuw van Weenen. Íslensk handrit, 3. Reykjavík.

Messuskýringar. 2014. Trans. Elise Kleivane. Ed. Sigurd Hareide, Kristin Norseth, and Elise Kleivane. Oslo.

Messuskýringar: Liturgisk symbolik frå den norsk-islandske kyrka i millomalderen. 1962.

Ed. Oluf Kolsrud. Oslo.

\section{Secondary Sources}

Aavitsland, Kristin B., Eivor Andersen Oftestad, and Ragnhild Zorgati. [forthcoming]. "Prelude." In Tracing the Jerusalem Code, Vol 1: The Holy City: Christian Cultures in Medieval Scandinavia (c.1100-1536). Ed. Kristin B. Aavitsland and Line M. Bonde.

Andås, Margarete Syrstad. 2007. “Art and Ritual in the Liminal Zone.” In The Medieval Cathedral of Trondheim: Architectural and Ritual Constructions in their European Context. Ed. Margarete Syrstad Andås, Øystein Ekroll, Andreas Haug, and Nils Holger Petersen. Ritus et Artes, 3. Turnhout. 47-126.

Bonde, Line M. [forthcoming]. "Jerusalem Commonplaces in Danish, Rural Churches: What Urban Architecture Remembers." In Tracing the Jerusalem Code, Vol 1: The Holy City: Christian Cultures in Medieval Scandinavia (c.1100-1536). Ed. Kristin B. Aavitsland and Line M. Bonde.

Böhme, Gernot. 1993. “Atmosphere as the Fundamental Concept of a New Aesthetics.” Thesis Eleven 36: 113-26.

Böhme, Gernot. 2017. Atmospheric Architecture: The Aesthetics of Felt Spaces. Trans. and ed. A.-Chr. Engels-Schwarzpaul. London and New York.

Carruthers, Mary. 1990. The Book of Memory: A Study of Memory in Medieval Culture. 2nd ed. Cambridge.

Carruthers, Mary. 1998. The Craft of Thought: Meditation, Rhetoric, and the Making of Images, 400-1200. Cambridge.

Carruthers, Mary. 2013. The Experience of Beauty in the Middle Ages. Oxford.

Crossley, Paul. 1988. "Medieval Architecture and Meaning: The Limits of Iconography." The Burlington Magazine 130.1019: 116-21.

Fernie, Eric. 2010. “Romanesque Architecture.” A Companion to Medieval Art. Ed. Conrad Rudolph. Malden. 295-313.

Gennep, Arnold van. 1981 [1909]. Les rites de passage, étude systématique des rites. Paris. Gombrich, Ernst H. 1979. The Sense of Order: A Study in the Psychology of Decorative Art. New York. 
Holly, Michael Ann. 1996. Past Looking: Historical Imagination and the Rhetoric of Image. Ithaca.

Hui, Allison, Theodore R. Schatzki, and Elizabeth Shove, eds. 2017. The Nexus of Practices: Connections, Constellations, Practitioners. New York.

Jürgensen, Martin Wangsgaard. 2018. Ritual and Art Across the Danish Reformation: Changing Interiors of Village Churches, 1450-1600. Ritus et artes, 6. Turnhout.

Kieffer-Olsen, Jakob. 2018. Kirke og kirkestruktur i middelalderens Danmark. University of Southern Denmark Studies in History and Social Sciences, 577. Odense.

Lang, Berel, ed. 1987 [1979]. The Concept of Style. Ithaca.

Latour, Bruno. 1993 [1991]. We Have Never Been Modern [Nous n'avons jamais été modernes]. Trans. Catherine Porter. Cambridge, MA.

Latour, Bruno. 2005. Reassembling the Social: An Introduction to Actor-Network-Theory. Oxford.

Lefebvre, Henri. 2009. The Production of Space. Malden.

Liepe, Lena, ed. 2018. The Locus of Meaning in Medieval Art: Iconography, Iconology, and Interpreting the Visual Imagery of the Middle Ages. Kalamazoo.

Nyborg, Ebbe. 1987. “Om kirkekunsten, kirkearkitekturen og middelalderens virkelighed.” In Tradition og historieskrivning. Kilderne til Nordens ældste historie. Ed. Kirsten Hastrup and Preben Meulengracht Sørensen. Acta Jutlandica, 63: 2. Aarhus. 85-93.

Pinotti, Andrea. 2012. "Formalism and the History of Style." In Art History and Visual Studies in Europe: Transnational Discourses and National Frameworks. Ed. Matthew Rampley, et al. Leiden. 75-90.

Postill, John. 2010. "Introduction: Theorizing Media and Practice." In Theorizing Media and Practice. Ed. Birgit Bräuchler and John Postill. Oxford and New York. 1-33.

Preziosi, Donald. 2009. The Art of Art History: A Critical Anthology. 2nd ed. Oxford.

Reckwitz, Andreas. 2002a. "The Status of the 'Material' in Theories of Culture: From 'Social Structure' to 'Artefacts'." Journal for the Theory of Social Behaviour 32.2: 195-217.

Reckwitz, Andreas. 2002b. "Towards a Theory of Social Practices: A Development in Culturalist Theorizing." European Journal of Social Theory 5: 243-63.

Reckwitz, Andreas. 2012. “Affective Spaces: A Praxeological Outlook.” Rethinking History 16.2: 241-58.

Reckwitz, Andreas. 2017. "Practices and Their Affects." In The Nexus of Practices: Connections, Constellations, Practitioners. Ed. Allison Hui, Theodore R. Schatzki, and Elizabeth Shove. New York. 114-25.

Riegl, Aloïs. 1893. Stilfragen: Grundlegungen zu einer Geschichte der Ornamentik. Berlin.

Schapiro, Meyer. 1953. "Style.” In Anthropology Today. Ed. A. L. Kroeber. Chicago. 287-312.

Schatzki, Theodore R. 1996. Social Practices: A Wittgensteinian Approach to Human Activity and the Social. Cambridge.

Schatzki, Theodore R., Karin Knorr Cetina, and Eike von Savigny, eds. 2001. The Practice Turn in Contemporary Theory. London and New York.

Vasari, Giorgio. 1968 [1550]. Lives of the Artists. Reprint ed. Harmondsworth.

Wienberg, Jes. 1993. Den gotiske labyrint. Middelalderen og kirkerne i Danmark. Stockholm.

Wittkower, Rudolf. 1973. "Genius: Individualism in Art and Artists." In Dictionary of the History of Ideas. Ed. Philip P. Wiener. New York. 297-313. 